\title{
Drivers of Engagement among Full-time Faculty from Private University
}

\author{
Gladys T. Tumbali ${ }^{a}$, Marie Jean Mendezabal ${ }^{\text {b }}$, Karen Joy Catacutan \\ ${ }^{\mathrm{a}, \mathrm{b}, \mathrm{c}}$ University of Saint Louis, Philippines
}

Article History: Received: 10 November 2020; Revised 12 January 2021 Accepted: 27 January 2021; Published online: 5 April 2021

\begin{abstract}
This study determined the drivers of engagement among full time faculty members of University of Saint Louis, one of the Private Higher Educational Institution in the Northern Philippines. The descriptive-survey method of research was employed using a validated questionnaire. The questionnaire was administered among ninety-eight (98) full-time faculty members in the University. Data was analyzed using descriptive and inferential statistics. Findings of the study revealed that the five drivers of faculty engagement which are (1) Administration and Management, (2) Workplace and Resources, (3) Compensation and Benefit, (4) Interpersonal Relationship, and (5) Achievement and Recognition, are all important factors that drive faculty to engage themselves in their jobs. Furthermore, results showed that Compensation and Benefits was found to be the most significant driver of faculty engagement, followed by Achievement and Recognition then Administration and Management. Meanwhile, Workplace and Resources as drivers of faculty engagement was found to be less important. Furthermore, results showed that the drivers of engagement among faculty vary by department and by the highest educational attainment
\end{abstract}

Keywords: Drivers of Job Engagement, Employee Engagement, Faculty Members, Private University

\section{Introduction}

Organizations need people, and people need organizations. The importance of inspiring and encouraging people to succeed has grown in importance in every company over time. Human resources have long been regarded as one of an organization's most valuable assets. Human resources are an organization's driving force, and maximizing their potential can go a long way toward improving efficiency and productivity (Wright \& McMahan, 2011; Ployhart\&Molterno, 2011). Employees that are engaged in their jobs are more efficient, and every company should understand the factors that influence employee engagement. Employee engagement is characterized as an employee's willingness and desire to help their organization succeed, primarily by providing discretionary effort on a long-term basis, and is influenced by a variety of factors, including both emotional and reasonable factors related to work and the overall work experience (Perrin's Global Workforce Study, 2003).

Over the years, one of the most difficult tasks facing many CEOs, HR professionals, and business leaders has been ensuring that when their employees return to work every day, they do so not only physically, but also psychologically and emotionally. In other words, they must be certain that their workers are fully engaged. Today, employee engagement has emerged as a key business engine. It has a direct impact on employee morale, efficiency, and reasons to stay with the organization. Engaged workers are being used as a strategic competence tool by businesses. Employees who are highly involved regularly outperform their peers and set new benchmarks (Bedarkar\&Pandita, 2014). Teachers play a critical role in the organization's success and long-term viability (Wiesner\&Yuniarti, 2018; Byun\& Kim, 2011; Lane \&McAndrew, 2010), especially in providing high-quality instruction and education to students (Calderon, Slavin\& Sanchez, 2011; Thoonen, Sleegers, Oort, Peetsma\&Geijsel, 2011). Employers must also be mindful of what motivates their workers to be productive and committed at work. Knowing these things will help workers cultivate a positive attitude toward their company, increase their understanding of the business background and function, and boost job and organizational effectiveness.

As a higher educational institution in the Northern Philippines, University of Saint Louis must keep its teaching staff professional and dedicated to delivering the products and services needed by its stakeholders in order to achieve mission and excellence. As a result, management should be mindful of the position of its teaching staff in terms of job satisfaction. As a result, identifying the drivers of job engagement among faculty members would aid in providing a clearer image of the University's full-time teaching staff in order to retain qualified teachers and provide quality education to its clients, which is the aim of this research.

Specifically it sought to achieve the following objectives: 
1. Determine the profile of the respondents in terms of department, age, sex, civil status, highest educational attainment and length of service.

2. Identify the drivers of job engagement along, administration and management, work place and resources, compensation and benefits, interpersonal relationships and achievement and recognition.

3. Determine if there is a significant difference on the drivers of engagement among faculty members when grouped according to their profile variables.

\section{Significance of the Study}

This study will provide insights among employers on the drivers of engagement among employees. Determining the drivers of engagement among faculty members would help provide a better picture of the University's teaching staff to maintain competent teachers to provide quality education for its clients. Moreover, knowing the drivers could help management develop a positive attitude of employees towards their organization and its values, wherein employees have awareness of business context and work to improve job and organizational effectiveness. Additionally, every organization needs to know the different dimensions of the drivers of employee engagement to make their employees more engaged to work, thus become more productive in the workplace.

\section{Methodology}

The study used a descriptive-survey research design to discover the factors that influence full-time faculty staff's job engagement. The research was carried out at the University of Saint Louis, a private educational institution in the Philippines' northern region. The study's respondents were full-time university faculty members for the 2016-2017 academic year who are still working at the university today. The research took into account a total of 98 faculty members (85 percent) who replied to the survey. The questionnaire used in the analysis was adapted from Comia\&Buenviaje's research (2016). However, several changes were made to suit the needs of the current report. The questionnaire was divided into two parts. The first section included the respondents' profiles, and the second section used a 4-point Likert Scale to identify the drivers of faculty job involvement in terms of administration and management policies, workplace and resources, compensation and benefits, interpersonal relationships, and achievement and recognition. 4=Strongly Agree, 3=Agree, 2=Disagree, and 1=Strongly Disagree on a scale of 1 to 4 . The tool was put through reliability testing as part of a pilot testing, and the test resulted in a score of 0.902 . The profile of the respondents and the drivers of faculty engagement were described using descriptive statistics such as frequency, percentage, and mean. Meanwhile, ANOVA and Independent Sample T-tests were used to see whether there was a significant difference in the drivers of faculty involvement when they were grouped according to their profile variables.

\section{Results and Discussion}

Table 1 presents the profile of the respondents. Majority of the respondents came from the Junior High School, 32 years old, female, and single. Most of them are college degree holders and have been in the University for six (6) years.

Table 1. Profile of the Respondents

\begin{tabular}{lll}
\hline Variables & Frequency & Percentage \\
\hline Department & 12 & $12.24 \%$ \\
Elementary & 30 & $30.61 \%$ \\
Junior High School & 11 & $11.22 \%$ \\
Senior High School & 14 & $14.29 \%$ \\
SABH & 20 & $20.40 \%$ \\
SEASH & 11 & $11.22 \%$ \\
SEADITE & & \\
Age & 58 & $59.18 \%$ \\
$21-30$ & 24 & $24.49 \%$ \\
$31-40$ & 12 & $12.24 \%$ \\
$41-50$ & 4 & $4.08 \%$ \\
$51-60$ & &
\end{tabular}


Mean Age $=32$

Sex

$\begin{array}{lll}\text { Male } & 30 & 30.61 \% \\ \text { Female } & 68 & 69.39 \%\end{array}$

Civil status

$\begin{array}{lll}\text { Single } & 56 & 57.14 \% \\ \text { Married } & 38 & 38.76 \% \\ \text { Widowed } & 4 & 4.08 \%\end{array}$

Highest Educational attainment

College Degree 55

$56.12 \%$

Master's Degree

$39.80 \%$

Doctorate

Length of service

$\begin{array}{lll}1-3 \text { years } & 41 & 41.84 \% \\ 4-6 \text { years } & 22 & 22.44 \% \\ 7-9 \text { years } & 9 & 9.18 \% \\ \text { 10 years and above } & 26 & 26.53 \% \\ \text { Ave. Number of Years of Service } & =6 \text { years }\end{array}$

Meanwhile, as shown in Table 2a, all dimensions are drivers of faculty engagement. Compensation and Benefits is found to be the most important driver of engagement especially for Senior High School, SEADITE and SEASH faculty while Administration and Management is recognized as the most important driver of engagement for the Elementary and SABH faculty. Moreover, Achievement and Recognition is a key determinant in enabling Junior High School faculty to engage with their work. Meanwhile, Workplace and Resources is found to be the weakest driver of engagement among faculty in the different schools except for SABH wherein Interpersonal Relationship is the weakest driver of engagement.

It further shows that there is a significant difference on the drivers of faculty engagement among departments. Result of the post hoc test revealed that the difference exists between the Elementary and SEASH department, JHS and SABH, and JHS and SEASH department.

Table 2a. Drivers of Faculty Engagement by Department

\begin{tabular}{|c|c|c|c|c|c|c|c|}
\hline \multirow{3}{*}{ nt } & \multicolumn{7}{|c|}{ Drivers of Faculty Engagement (Mean) } \\
\hline & \multirow{2}{*}{ Departme } & Administr & Workpl & Compensat & \multirow{2}{*}{$\begin{array}{l}\quad \text { Interperso } \\
\text { nal } \\
\text { Relationship }\end{array}$} & \multirow{2}{*}{$\begin{array}{l}\text { Achievem } \\
\text { ent and } \\
\text { Recognition }\end{array}$} & \multirow{2}{*}{$\begin{array}{l}\text { Drivers of } \\
\text { Engagem } \\
\text { ent }\end{array}$} \\
\hline & & $\begin{array}{l}\text { ation and } \\
\text { Management }\end{array}$ & $\begin{array}{l}\text { ace and } \\
\text { Resources }\end{array}$ & $\begin{array}{ll}\text { ion } & \text { and } \\
\text { Benefits } & \end{array}$ & & & \\
\hline ry & Elementa & 3.45 & 3.19 & 3.39 & 3.36 & 3.35 & 3.35 \\
\hline & JHS & 3.56 & 3.31 & 3.66 & 3.61 & 3.71 & 3.57 \\
\hline & SHS & 3.18 & 2.92 & 3.53 & 3.17 & 3.20 & 3.20 \\
\hline & SABH & 2.99 & 2.90 & 2.79 & 2.49 & 2.65 & 2.76 \\
\hline & SEASH & 2.65 & 2.68 & 3.04 & 2.80 & 2.99 & 2.83 \\
\hline $\mathrm{E}$ & SEADIT & 3.05 & 3.05 & 3.35 & 3.33 & 3.11 & 3.18 \\
\hline
\end{tabular}




$\begin{array}{ccccccc}\begin{array}{c}\text { Overall } \\ \text { Mean }\end{array} & 3.15 & 3.01 & 3.29 & 3.13 & 3.17 & 3.15 \\ \text { F-value } & 9.486 & 5.500 & 9.486 & 9.486 & 5.500 & 8.714 \\ \text { p-value } & .000 & .000 & .000 & .000 & .000 & .000\end{array}$

Legend: $1.00-1.49-$ not a driver; $1.50-2.49$ - somewhat a driver; $2.50-3.49-$ a driver; $3.50-4.00-\mathrm{a}$ significant driver

Next, in table $2 b$, Compensation and Benefits is considered as the most important driver of faculty engagement for all age groups especially for faculty whose age ranged from 51 to 60 years old. On the other hand, Workplace and Resources is the least important factor that drives faculty engagement. The data further reveals that there is no significant difference on the drivers of faculty engagement when grouped by age. This means that faculty regardless of age do not vary in terms of their drivers of engagement.

Table 2b. Drivers of Faculty Engagement by Age

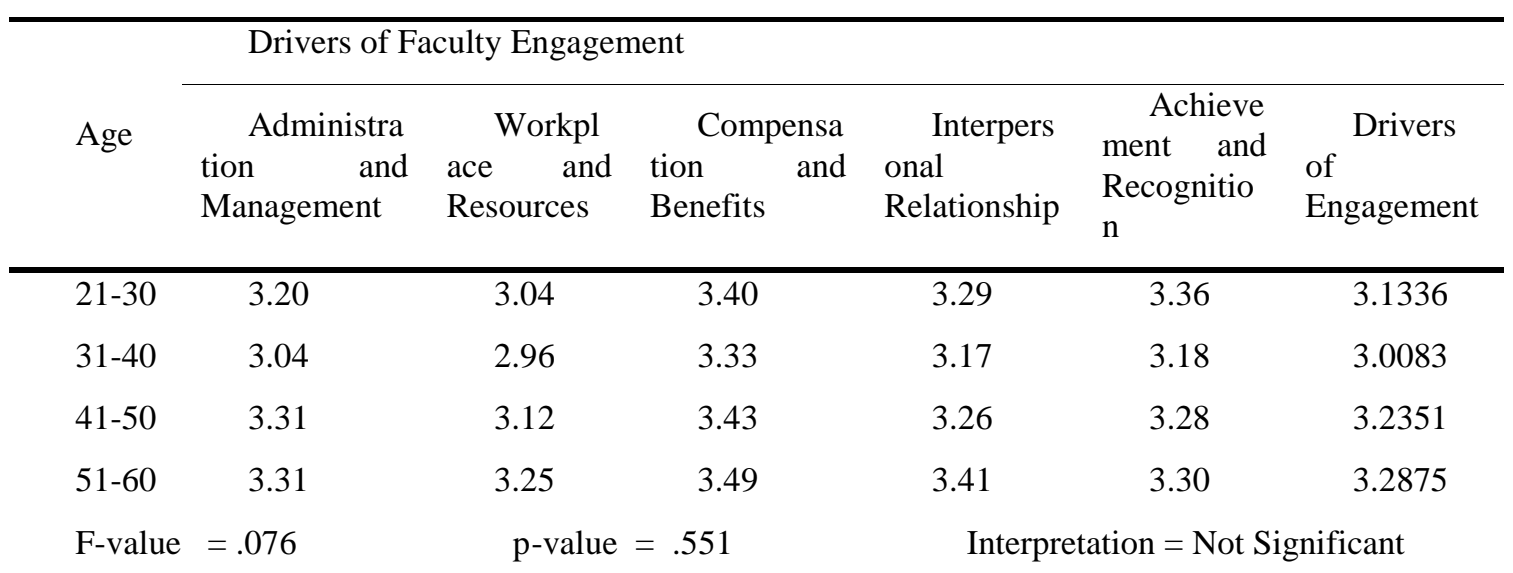

Table 2c shows that for both male and female faculty, the main driver of faculty engagement is Compensation and Benefits. Also, Achievement and Recognition is a key determinant in facilitating engagement among male and female faculty members. The result further shows that the drivers of faculty engagement are not significantly different for male and female faculty members.

Table 2c. Drivers of Faculty Engagement by Sex

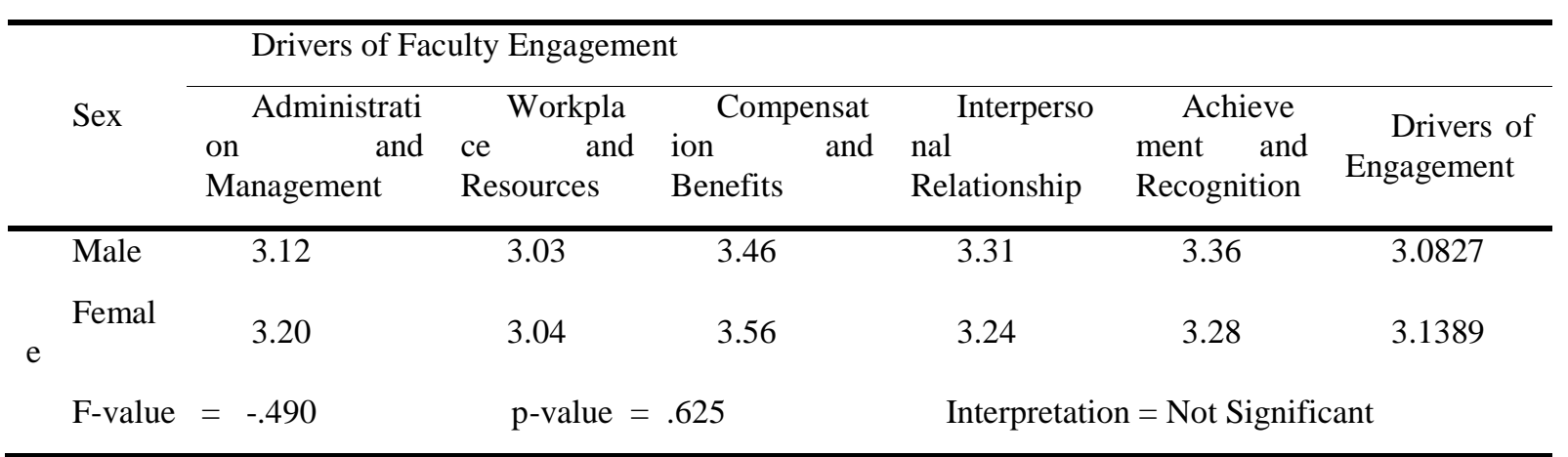

It can be inferred from table $2 \mathrm{~d}$ that all dimensions are drivers of faculty engagement. However, Compensation and Benefits is found to be the most important driver among the respondents especially among the widowed faculty. Findings of the study likewise reveal that the drivers of faculty engagement do not vary among respondents when grouped according to civil status.

Table 2d. Drivers of Faculty Engagement by Civil Status

\begin{tabular}{|c|c|c|c|c|c|c|}
\hline \multirow{4}{*}{$\begin{array}{l}\text { Civil } \\
\text { status }\end{array}$} & \multicolumn{6}{|c|}{ Drivers of Faculty Engagement } \\
\hline & Administra & Workpl & Compensat & Interperso & Achieve & Drivers \\
\hline & tion and & ace and & ion and & & ment and & \\
\hline & Management & Resources & Benefits & Relationship & Recognition & Engagement \\
\hline Single & 3.16 & 2.99 & 3.39 & 3.24 & 3.34 & 3.0929 \\
\hline
\end{tabular}




\begin{tabular}{|c|c|c|c|c|c|c|}
\hline Married & 3.22 & 3.09 & 3.39 & 3.23 & 3.29 & 3.1718 \\
\hline Widowe & 3.03 & 3.07 & 3.46 & 3.00 & 2.95 & 3.0473 \\
\hline F-value & 297 & $p$-value & & Interpr & Jot $\mathrm{Sig}$ & \\
\hline
\end{tabular}

As disclosed in Table 2e, the key enabler of faculty engagement is Compensation and Benefits. It further shows that Achievement and Recognition is also important in inspiring faculty members to engage in their job especially among bachelor's degree holders and those with doctorate degree. Moreover, the data shows variation on the drivers of faculty engagement when grouped according to highest educational attainment. Further analysis using multiple comparisons revealed that the difference exists between college degree holders and those with doctorate degrees. Faculty members who are bachelor's degree holders are strongly impacted by the effect of Compensation and Benefit as compared with those with doctorate degree.

Table 2e. Drivers of Faculty Engagement by Highest Educational attainment

\begin{tabular}{|c|c|c|c|c|c|c|}
\hline \multirow{4}{*}{$\begin{array}{l}\text { Highest } \\
\text { Educational } \\
\text { attainment }\end{array}$} & \multicolumn{3}{|c|}{ Drivers of Faculty Engagement } & \multirow{4}{*}{$\begin{array}{l}\text { Interperso } \\
\text { nal } \\
\text { Relationship }\end{array}$} & \multirow[b]{2}{*}{ Achieve } & \multirow{4}{*}{$\begin{array}{l}\text { Drivers } \\
\text { of } \\
\text { Engagement }\end{array}$} \\
\hline & Administra & Workpl & Compensat & & & \\
\hline & tion and & ace and & ion and & & ment and & \\
\hline & Management & Resources & Benefits & & Recognition & \\
\hline Bachelor & 3.33 & 3.12 & 3.49 & 3.37 & 3.44 & 3.2485 \\
\hline Master's & 2.97 & 2.86 & 3.13 & 3.05 & 3.00 & 2.9241 \\
\hline Doctorat & 2.98 & 2.93 & 3.27 & 3.13 & 3.26 & 2.9630 \\
\hline F-value & 3.946 & $\mathrm{p}$-value $=$ & 023 & Interpretation & Significant & \\
\hline
\end{tabular}

Lastly, as gleaned from table $2 \mathrm{f}$, Compensation and Benefits is the most essential driver of engagement among faculty who have been in the University for at most 6 years and those who served for at least 10 years. Also, Interpersonal Relationship is found to be the most important factor of engagement for faculty who have been in the University for 7 to 9 years. Moreover, it is shown that the drivers of faculty engagement do not vary among faculty when grouped according to length of service.

Table 2f. Drivers of Faculty Engagement by Length of service

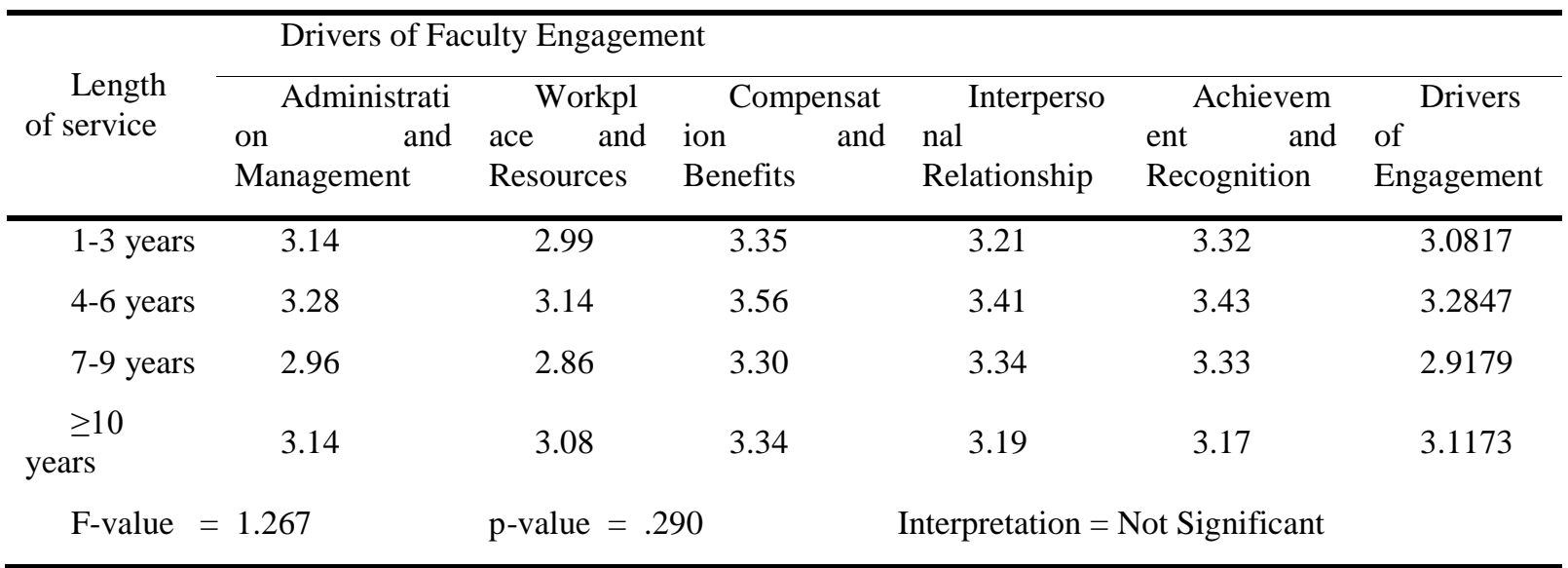

The study determines the drivers of faculty engagement among USL faculty members. Findings of the study revealed that the five drivers of faculty engagement namely Administration and Management Policies, Workplace and Resources, Compensation and Benefits, Interpersonal Relationship, and Achievement and Recognition are important factors affecting faculty engagement. Generally, Compensation and Benefits, and Rewards and Recognition are found to be the most significant driver of faculty engagement especially among faculty members in the Senior High School, SEASH, and SEAIDITE. This implies that Compensation and Benefits, and Rewards and Recognition are really important in instilling faculty engagement. Faculty members who are provided with reasonable compensation and benefits and who are recognized and rewarded for their services or work are more likely to engage in their work and in the university. 
Job satisfaction refers to an employee's optimistic feelings and attitudes about their work. It stems from the belief that an employee's role offers just what he or she values in the workplace (Nguini, Sleegers, \&Denessen, 2006; Evans, 2001; Bogler, 2001). Relationships in the working environment (Crossman \& Harris, 2006), compensation and remuneration, school and physical environment (Collie, Shapka, \& Perry, 2012; Skaalvik\&Skaalvik, 2009) were all identified as important aspects for job satisfaction in the literature on teacher job satisfaction, especially in higher education institutions (Huysman, 2007).

Meanwhile, the importance of Administration and Management in driving faculty engagement is revealed in the study especially among the Elementary and SABH faculty. This result suggests that maintaining a high ethical standard in the workplace is a significant driver of faculty engagement. Moreover, awareness of the University's existing policies has enabled the faculty members to get engaged in their work. Also, it is important that employees are given opportunities to get involved especially when important decisions are made as this helps them feel being valued in their work. According to Robinson, et al., (2004), the main factor of employee engagement is a sense of being respected and engaged, which involves elements such as involvement in decisionmaking, the degree to which employees feel able to voice their opinions, the opportunities employees have to improve their careers, and the extent to which the company is concerned about the well-being of its employees.

Furthermore, involving workers in decision-making will meet their needs, resulting in increased job participation. Furthermore, when employees have a better understanding of the compensation policies, services, and processes in place, they are more engaged. Good contact between the employer and employees, as well as among coworkers, is the foundation of long-term commitment (Training, 2012). Employees who work in an environment where respect is respected are more active. A manager's attitude of consideration for the employee and equal treatment of the employees entails whether the manager will listen to the employee's ideas or suggestions, whether the employee will feel respected, and whether the manager will be able to interact effectively with the employees. Involvements that cross over into daily practice serve as motivators, making workers feel respected and thereby the commitment (Paton \&Karunaratne, 2009).

Result of the study further showed that Achievement and Recognition is a key determinant in enabling Junior High School faculty to engage with their work. This means that the more heads/supervisors appreciate their faculty members' accomplishments, the more active the faculty member is at work. Employees in highly active organizations have many opportunities to learn new skills, improve talents, gain experience, and realize their full potential. Career development practices aid in the retention of talented workers while also providing opportunities for personal growth. Employees are more likely to invest in businesses that invest in them by providing opportunities for advancement (Bhatla, 2011). Employee involvement is influenced by their professional advancement (Kular, Gatenby, Rees, Soane\& Truss, 2008). Employee growth through training, skills, and learning may also result in workers becoming more involved in their jobs and organizations (Andrew \&Sofian 2012).

Furthermore, it was shown from the result of the study that there is variation on the drivers of engagement among faculty members by departments and by the highest educational attainment. The distinction between those with a bachelor's degree and those with a doctorate degree was demonstrated. This means that faculty members with a bachelor's degree place a higher value on compensation and benefits than those with a doctorate degree. Comia\&Buenviaje (2016) found that age and educational attainment had a major impact on job participation. According to a Gallup/Lumina foundation report (2012), those with a higher level of education were marginally less likely to be deliberately disengaged than those with a high school diploma, technical/vocational training, or some college, as cited by Comia\&Buenviaje (2016). Their findings indicate that having a college degree will help employees avoid being stuck in a job by giving them more job opportunities and enabling them to be more selective about the jobs they take. Despite the expected economic benefits of a more skilled workforce, it seems that employers are doing very little to engage this influx of college graduates in their workplaces. Leaders must understand more about the individual needs and desires of these workers in order to create tailored, measurable action plans that align with organizational goals. Faculty participation, on the other hand, is unaffected by age, gender, civil status, or duration of service.

\section{Conclusion and Recommendations}

Understanding the drivers of faculty engagement is very important in nurturing faculty engagement. In this study, the five drivers of faculty engagement which are Administration and Management Policies, Workplace and Resources, Compensation and Benefits, Interpersonal Relationship, and Achievement and Recognition are all important factors that drive faculty engagement. Compensation and Benefits is the strongest driver of faculty engagement followed by Achievement and Recognition, and Administration and Management Policies. The Workplace and Resources was found to be least important driver among faculty members.

Based on the findings of the study, it can be recommended that employee engagement should be a continuous process to be integrated in the culture of the University in fulfilling organizational goals as well as personal goals 
of employees. Top management may revisit the Performance Management System (PMS) for its possible implementation to strengthen the salary structure of employees as this is the primary driver of engagement. Also, to revisit the policies on giving monetary rewards for achievements obtained by faculty members. Lastly, for the Administration to strengthen the implementation of policies in maintaining high ethical standards in the University..

\section{References}

Andrew, O. C., \&Sofian, S. (2012). Individual factors and work outcomes of employee engagement. ProcediaSocial and behavioral sciences, 40, 498-508.

Bedarkar, M., \&Pandita, D. (2014). A study on the drivers of employee engagement impacting employee performance. Procedia-Social and Behavioral Sciences, 133, 106-115.

Bhatla, N. (2011). To study the Employee Engagement practices and its effect on employee performance with special reference to ICICI and HDFC Bank in Lucknow. International Journal of Scientific \& Engineering Research, 2(8), 1-7.

Bogler, R. (2002). Two profiles of schoolteachers: A discriminant analysis of job satisfaction. Teaching and Teacher Education, 18(6), 665-673.

Byun, K., \& Kim, M. (2011). Shifting patterns of the government's policies for the internationalization of Korean higher education. Journal of Studies in International Education, 15(5), 467-486.

Calderón, M., Slavin, R., \& Sanchez, M. (2011). Effective instruction for English learners. The future of children, 103-127.

Collie, R. J., Shapka, J. D., \& Perry, N. E. (2012). School climate and social-emotional learning: Predicting teacher stress, job satisfaction, and teaching efficacy. Journal of educational psychology, 104(4), 1189.

Comia, J. R., \&Buenviaje, M. G. (2016). Workforce Engagement among Employees of Citimart Head Office. Asia Pacific Journal of Academic Research in Business Administration, 2(1).

Crossman, A., \& Harris, P. (2006). Job satisfaction of secondary school teachers. Educational Management Administration \& Leadership, 34(1), 29-46.

Evans, L. (2001). Delving deeper into morale, job satisfaction and motivation among education professionals: Re-examining the leadership dimension. Educational Management \& Administration, 29(3), 291-306.

Kular, S., Gatenby, M., Rees, C., Soane, E., \& Truss, K. (2008). Employee engagement: A literature review.

Huysman, J. (2007). Rural Teacher Satisfaction: An Analysis OfBeliefsand Attitudes Of Rural Teachers' Job Satisfaction.

Lane, A., \&McAndrew, P. (2010). Are open educational resources systematic or systemic change agents for teaching practice?. British Journal of Educational Technology, 41(6), 952-962.

Nguni, S., Sleegers, P., \&Denessen, E. (2006). Transformational and transactional leadership effects on teachers' job satisfaction, organizational commitment, and organizational citizenship behavior in primary schools: The Tanzanian case. School effectiveness and school improvement, 17(2), 145-177.

Paton, R., \&Karunaratne, N. (2009). Engagement and innovation: the Honda case. VINE.

Perrin T. (2003). Working today: Understanding what drives employee engagement.

Ployhart, R. E., \&Moliterno, T. P. (2011). Emergence of the human capital resource: A multilevel model. Academy of management review, 36(1), 127-150.

Robinson, D., Perryman, S., \&Hayday, S. (2004). The drivers of employee engagement. Institute for Employment Studies.

Skaalvik, E. M., \&Skaalvik, S. (2009). Does school context matter? Relations with teacher burnout and job satisfaction. Teaching and teacher education, 25(3), 518-524.

Thoonen, E. E., Sleegers, P. J., Oort, F. J., Peetsma, T. T., \&Geijsel, F. P. (2011). How to improve teaching practices: The role of teacher motivation, organizational factors, and leadership practices. Educational administration quarterly, 47(3), 496-536.

Training, D. C. (2012). What drives employee engagement and why it matters. Dale Carnegie Training White Paper, 1-6.

Wiesner, G., \&Yuniarti, N. (2018). Systematic Quality Management in Vocational Educational Institutes: Role of Teachers in Development of Organizational Quality. JurnalPendidikanTeknologidanKejuruan, 24(1), 162170.

Wright, P. M., \& McMahan, G. C. (2011). Exploring human capital: putting 'human'back into strategic human resource management. Human resource management journal, 21(2), 93-104. 